\title{
Effective Immunosurveillance After Allogeneic Hematopoietic Stem Cell Transplantation in Acute Myeloid Leukemia
}

\section{Desiree Kunadt \\ Friedrich Stölzel}

Department of Internal Medicine I, University Hospital Carl Gustav Carus, Technical University of Dresden, Dresden, Germany
Correspondence: Friedrich Stölzel Department of Internal Medicine I, University Hospital Carl Gustav Carus, Technical University of Dresden, Fetscherstrasse 74, Dresden, 0I307, Germany

Tel +49 35I 458 I9475

Fax +49 35I 4585362

Email friedrich.stoelzel@ukdd.de

\begin{abstract}
The number of patients receiving allogeneic hematopoietic stem cell transplantation (alloHCT) has increased constantly over the last years due to advances in transplant technology development, supportive care, transplant safety, and donor availability. Currently, acute myeloid leukemia (AML) is the most frequent indication for alloHCT. However, disease relapse remains the main cause of therapy failure. Therefore, concepts of maintaining and, if necessary, reinforcing a strong graft-versus-leukemia $(\mathrm{GvL})$ effect is crucial for the prognosis and long-term survival of the patients. Over the last decades, it has become evident that effective immunosurveillance after alloHCT is an entangled complex of donor-specific characteristics, leukemia-associated geno- and phenotypes, and acquired resistance mechanisms. Furthermore, adoption of effector cells such as natural killer (NK) cells, alloreactive and regulatory T-cells with their accompanying receptor repertoire, and cell-cell interactions driven by messenger molecules within the stem cell and the bone marrow niche have important impact. In this review of pre- and posttransplant elements and mechanisms of immunosurveillance, we highlight the most important mechanisms after alloHCT.
\end{abstract}

Keywords: acute myeloid leukemia, AML, allogeneic stem cell transplantation, alloHCT, graft-versus-leukemia, GvL, relapse, immunosurveillance

\section{Introduction}

Allogeneic hematopoietic stem cell transplantation (alloHCT) is currently the leading consolidation treatment for high-risk malignant hematologic diseases like acute myeloid leukemia (AML) with a potentially curative approach and increasing numbers of transplants performed each year worldwide. ${ }^{1-5}$ In fact, AML is the most common disorder for which alloHCT is used. ${ }^{4}$ For AML patients having intermediate- or adverse-risk genetic alterations, as well as relapsed or refractory disease, alloHCT achieves the highest rates of long-term survival as post remission or combined salvage treatment. ${ }^{6-8}$ Still, disease relapse remains the main cause of treatment failure. ${ }^{9,10}$ In case of relapse, the prognosis is generally very poor despite comprehensive salvage therapies. ${ }^{11-16}$ This stresses the vital role of a strong antileukemic effect in the alloHCT setting.

The key mechanism for durable remissions is preserving a graft-versus-leukemia $(\mathrm{GvL})$ effect targeting residual disease after intense conditioning therapy and sustained engraftment. ${ }^{17}$ Donor-derived alloreactive cytotoxic CD8+ T-cells play an important part in mediating GvL disease control by recognizing leukemia-specific antigens, eg, major and minor histocompatibility antigens, thereby conferring anti-leukemia 
alloreactivity. The concept of GvL was established after several observations showed an increased risk of relapse after matched-sibling or T-cell depleted transplantation while lowering the risk of acute graft-versus-host disease (GvHD). ${ }^{17}$ Vice versa, decreasing the risk of relapse by tolerating acute and chronic GvHD, respectively, and retrieving disease control by donor lymphocyte infusions (DLI) in case of imminent relapse has unveiled the delicate interconnection between GvL and GvHD. ${ }^{17-19}$

With the awareness of an immunologic GvL effect, the use of less intensive conditioning regimens became more feasible in the transplant setting. Therefore, it has broadened the spectrum of patients with AML being eligible for an intensive treatment like allogeneic HCT as a curative therapy worldwide. $^{20,21}$ Currently, alloHCT can now be offered to many fit elderly patients with acceptable toxicity. ${ }^{22}$

However, achieving and enhancing a strong GvL effect while minimizing GvHD reactions is still a challenging endeavor in clinical practice and a major goal of translational research. Although GvHD and GvL appear to be concomitant phenomena in clinical practice, subsequent reports have highlighted the differences in between these two posttransplant events, yielding clinical potential to offer proper GvHD prophylaxis while the GvL effect remains unaffected for disease control. ${ }^{23-26}$ Preserving a sufficient GvL effect is a complex interplay of different cellular components and characteristics, involving the interaction of the immune environment and immune system components, efficacy of allogeneic T-cell reactivity, leukemia-specific features, potential and side effects of conditioning intensity, applied GvHD prophylaxis, and anti-leukemic potential of specific maintenance therapy (Figure 1). The complexity of immunosurveillance after alloHCT is still not fully understood yet. Providing sufficient immunosurveillance will optimize outcome after alloHCT noticeably and improve the prognosis of AML patients (Table 1). Whether further

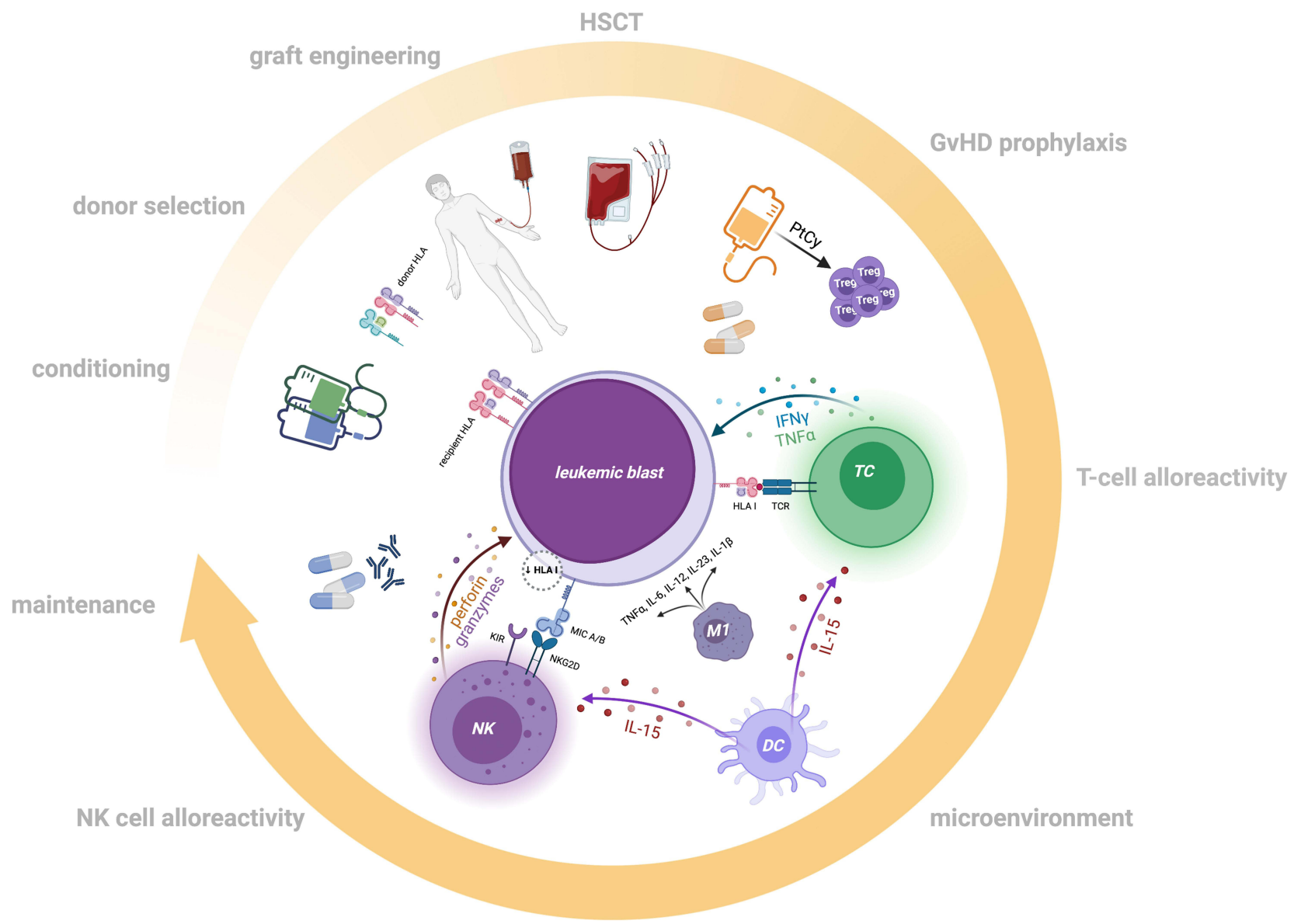

Figure I Components associated with Graft versus Leukemia activity. This cartoon depicts the main components associated with Graft versus Leukemia (GvL) and the interdependency of anti-leukemic alloreactivity. During the course of alloHCT several factors are crucial to support and provide a strong GvL effect. These elements include: intensity of conditioning, donor-specific characteristics (eg, HLA profile [red/violet shared alleles, blue/green mismatched alleles], sex, age, and kinship), stem cell source and graft engineering, cellular composition of the graft, effects of GvHD prophylaxis, effector T-cells and NK cells, microenvironmental features and targeted maintenance therapies (eg, HMAs, TKIs, and antibodies). Figure created with BioRender.com. 
Table I Clinical Trials Addressing Augmentation of Graft versus Leukemia

\begin{tabular}{|c|c|c|c|c|}
\hline Approach & Trial & Population Characteristics & $\mathbf{N}$ & Main Outcomes \\
\hline \multirow[t]{2}{*}{ DLI } & $\begin{array}{l}\text { Schmid } \\
C \text { et al } \\
2007^{13}\end{array}$ & $\begin{array}{l}\text { (i) } r / r \text { AML } \geqq 16 \text { years after alloHCT } \\
\text { (ii)RIC or MAC } \\
\text { (iii)HLA identical donor or other }\end{array}$ & 339 & $\begin{array}{l}\text { Remission vs no remission at time of DLI administration } \\
\text { significant prognostic factor for OS (RR for OS } 5.8[95 \% \\
\text { Cl } 2.5-13.7], \mathrm{P}<0.000 \mathrm{I} \text { ) }\end{array}$ \\
\hline & $\begin{array}{l}\text { Schmid } \\
C \text { et al } \\
2019^{100}\end{array}$ & $\begin{array}{l}\text { (i)AML or ALL } \geqq 18 \text { years } \\
\text { (ii)RIC or MAC } \\
\text { (iii)MSD or MUD }\end{array}$ & 178 & $\begin{array}{l}\text { Improved outcome in high-risk AML (OS: prophylactic } \\
\text { DLIs } 69.8 \% \text { vs } 40.2 \% \text { in controls, } p=0.027 \text { ) }\end{array}$ \\
\hline \multirow[t]{2}{*}{ NK } & $\begin{array}{l}\text { Ciurea } \\
\text { S et al } \\
2017^{120}\end{array}$ & $\begin{array}{l}\text { (i)High risk AML, MDS or CML I8-60 years after } \\
\text { alloHCT } \\
\text { (ii)Flu/Mel with I dose } 200 \text { cGy TBI } \\
\text { (iii)haploHCT }\end{array}$ & 13 & $\begin{array}{l}\text { Significantly improved NK-cell number and function, lower } \\
\text { viral infections, and low relapse rate posttransplant }\end{array}$ \\
\hline & $\begin{array}{l}\text { Ruggeri } \\
\text { L et al } \\
2021^{113}\end{array}$ & $\begin{array}{l}\text { (i)AML or ALL } \\
\text { (ii)RIC or MAC } \\
\text { (iii)haploHCT }\end{array}$ & 138 & $\begin{array}{l}\text { NK cell alloreactivity with no impact on GRFS in } \\
\text { unmanipulated grafts (HR I.66 [95\% Cl 0.9-3.I], p = 0.I), } \\
\text { but beneficial impact on GRFS in T-cell-depleted } \\
\text { transplants (HR } 0.6 \text { [ } 95 \% \mathrm{Cl} 0.3-1.2] \text {, interaction } \mathrm{p}< \\
0.00 \mathrm{I} \text { ) }\end{array}$ \\
\hline CIK & $\begin{array}{l}\text { Laport } \\
\text { G et al } \\
2011^{173}\end{array}$ & $\begin{array}{l}\text { (i)Relapsed AML, APL, ALL, CLL, NHL, MM, MDS } \\
\text { or } H L \geqq 18 \text { years after alloHCT } \\
\text { (ii)RIC or MAC } \\
\text { (iii)MSD }\end{array}$ & 18 & $\begin{array}{l}\text { Median EFS } 4 \text { months, median time to relapse } 6 \text { months } \\
\text { (range } 2-37 \text { months), median OS } 28 \text { months }\end{array}$ \\
\hline \multirow[t]{2}{*}{$\mathrm{ICi}$} & $\begin{array}{l}\text { Davids } \\
\text { M et al } \\
2016^{150}\end{array}$ & $\begin{array}{l}\text { (i)Refractory/progressive AML, AML with } \\
\text { extramedullary disease, ALL, MM, NHL, HL, MDS } \\
\text { or MPN } \geqq 18 \text { years after alloHCT } \\
\text { (ii)RIC or MAC } \\
\text { (iii)Related or unrelated donor }\end{array}$ & 28 & $\begin{array}{l}\text { Ipilimumab dose of } 10 \mathrm{mg} / \mathrm{kg} \text { : } 23 \% \text { complete response, } 9 \% \\
\text { partial response, } 27 \% \text { decreased tumor burden, complete } \\
\text { responses in patients with extramedullary AML; } 4 \text { patients } \\
\text { with durable response for more than I year; } \\
\text { Immune-related adverse events } 21 \%\end{array}$ \\
\hline & $\begin{array}{l}\text { Daver } \\
\mathrm{N} \text { et al } \\
2019^{153}\end{array}$ & $\begin{array}{l}\text { (i)r/r AML } \geqq 22 \text { years } \\
\text { (ii)additional azacitidine treatment }\end{array}$ & 70 & $\begin{array}{l}\text { ORR } 33 \% \text { : } 22 \% \text { CR/CRi, I partial response, } 10 \% \text { with } \\
\text { hematologic improvement, } 9 \% \text { stable disease; ORR } 58 \% \\
\text { HMA-naïve vs } 22 \% \text { HMA-pretreated; Grade } 3 \text { to } 4 \\
\text { immune-related adverse events II } \%\end{array}$ \\
\hline \multirow[t]{2}{*}{$T K I$} & $\begin{array}{l}\text { Mathew } \\
\mathrm{N} \text { et al } \\
2018^{118}\end{array}$ & $\begin{array}{l}\text { (i)In vitro murine and human models } \\
\text { (ii) Relapsed FLT3-ITD }{ }^{\text {mut }} A M L\end{array}$ & l & $\begin{array}{l}\text { Sorafenib increases IL-I5 production by FLT3-ITD }{ }^{\text {mut }} \\
\text { leukemic cells and CD } 8+C D 107 a+I F N-\gamma+\text { allogeneic } \\
\text { T-cells }\end{array}$ \\
\hline & $\begin{array}{l}\text { Burchert } \\
\text { A et al } \\
2020^{127}\end{array}$ & $\begin{array}{l}\text { (i)FLT3-ITD }{ }^{\text {mut }} A M L \geqq 18 \text { years } \\
\text { (ii)Hematologic } C R \text { after alloHCT }\end{array}$ & 83 & $\begin{array}{l}\text { Sorafenib maintenance lowers risk of relapse/death (HR } \\
0.39[95 \% \mathrm{Cl} 0.18-0.85], \mathrm{p}=0.013) \text { and improves RFS }(\mathrm{HR} \\
0.256[95 \% \mathrm{Cl} 0.10-0.65], \mathrm{p}=0.002) \text { after alloHCT for } \\
\text { FLT3-ITD }{ }^{\text {mut }} \text { AML }\end{array}$ \\
\hline
\end{tabular}

Abbreviations: ALL, acute lymphoblastic leukemia; alloHCT, allogeneic hematopoietic stem cell transplantation; AML, acute myeloid leukemia; APL, acute promyelocytic leukemia; cGy, centigray; Cl, confidence interval; CIK, cytokine-induced killer cells; CLL, chronic lymphocytic leukemia; CML, chronic myeloid leukemia; CR, complete remission; CRi, complete remission with insufficient recovery of counts; DLI, donor lymphocyte infusion; EFS, event free survival; Flu, fludarabine; FLT3-ITD ${ }^{\text {mut }}$, mutated Fms-related tyrosine kinase 3 internal tandem duplication; GRFS, GvHD/relapse-free survival; haploHCT, haploidentical hematopoietic stem cell transplantation; HL, Hodgkin's lymphoma; HLA, human leukocyte antigen; HMA, hypomethylating agent; HR, hazard ratio; ICi, immune checkpoint inhibitors; MAC, myeloablative conditioning; MDS, myelodysplastic syndrome; Mel, melphalan; MM, multiple myeloma; MPN, myeloproliferative neoplasm; MSD, matched sibling donor; MUD, matched unrelated donor; $\mathrm{NHL}$, non-Hodgkin lymphoma; NK, natural killer cells; ORR, overall response rate; OS, overall survival; RFS, relapse free survival; RIC, reduced intensity conditioning; RR, relative risk; r/r, relapsed/refractory; TBI, total body irradiation; TKI, tyrosine kinase inhibitor.

cell-based therapies such as chimeric antigen-receptor (CAR) T-cell therapies in combination with alloHCT will add further anti-leukemic pressure is still a matter of debate and will be investigated in the near future.

\section{Donor-Specific Characteristics Human Leukocyte Antigen (HLA) Profile} Disparities in HLA class I (HLA-A, -B, -C) and class II (HLA-DRB1, -DQB1, -DPB1) have important 
implications for both GvHD and GvL. In fact, the HLA region is the most polymorphic system with 17.191 class I and 6.716 class II alleles described to date. ${ }^{27}$ With the beginning of HLA typing, first as a serologic approach spanning HLA-A, -B, -C, and -DRB1, and later as a highthroughput next-generation sequencing-based technique broadening our knowledge of the HLA system, donor availability, and allowing the usage of unrelated donors, paralleled by dramatically rising numbers of donor volunteers (approximately 38 million in 2021; World Marrow Donor Association [WMDA], https://statistics.wmda.info), alloHCT has become a safe and widely used treatment option.

Despite the huge number of volunteers, approximately $10 \%$ of patients in need of an allograft lack an HLAmatching related or unrelated donor. A higher degree of HLA disparity is associated with a higher transplantrelated mortality (TRM) and lower overall survival (OS) compared to well-matched donors. ${ }^{28,29}$ Notably, comparison of mismatched settings, eg, partially matchedunrelated donors (MMUD) and related haploidentical donors (MMRD) suggests comparable outcomes, as nonrelapse mortality (NRM), relapse rate, and occurrence of GvHD did not differ significantly in retrospective studies. ${ }^{30}$ By contrast, a higher number of HLA mismatches were associated with increased event-free survival (EFS) ${ }^{31}$ One could easily argue that greater HLA disparity leads to an enhanced GvL effect because of higher numbers of displayed unshared HLA epitopes with supporting data showing decreased relapse rates, though no survival benefit was achieved because of increased NRM. ${ }^{32}$ Nevertheless, prospective studies comparing MMUD with MMRD in times of refined GvHD prophylaxis are still ongoing and are expected to shed light on one of the most open questions in the transplant community to evaluate OS in MMUD versus MMRD (NCT03275636) and MUD versus MMRD (NCT04232241).

Considering functional HLA class II mismatches, donors harboring an HLA-DPB1 graft-versus-host (GvH) disparity have been associated with a reduced risk of relapse as mismatched HLA-DPB1 is a target structure for alloreactive T-cells. ${ }^{33,34}$ Further studies have found that HLA-DRB1 mismatches in the GvH direction are also associated with an improved survival because of reduced NRM. ${ }^{32}$ Even smallest sequence dimorphisms like the concept of HLA-B M- and T-leader peptides, describing single nucleotide variants in exon one of the
HLA-B allele, strongly affect T-cell and natural killer (NK) cell alloresponses. ${ }^{35}$ These data underline the importance of deciphering pro-GvL and pro-GvHD-associated HLA alleles and antigens as a main goal for future studies to improve donor selection and achieve maximum therapeutic success.

\section{Donor Age}

In addition to donor/recipient HLA profile concordance, sex, parity, cytomegalovirus (CMV) serostatus, and blood group $\mathrm{ABO}$ match, donor age has become one of the major determinants for survival after unrelated alloHCT, with a reported $5.5 \%$ increase for overall mortality for every 10 -year increment in donor age. ${ }^{36}$ The advantage of younger donor age could also be associated with a significantly lower rate of acute and chronic GvHD. ${ }^{37}$ Interestingly, the benefit of younger donor age is more important in older recipients ( $>40$ years) than in younger patients with AML in a haploidentical setting. ${ }^{38}$ Likewise, younger donor age ( $\leq 40$ years) was determined as an independent predictor for better OS in older AML patients ( $\geq 55$ years) receiving haploHCT. ${ }^{39}$ Noteworthy, donor age appears to have no adverse effects on functional fitness of hematopoietic cells after alloHCT. ${ }^{40}$ A recently published retrospective multicenter analysis of a large cohort of haploHCTs using posttransplant cyclophosphamide (PtCy) as GvHD prophylaxis confirmed a higher incidence of acute GvHD and a trend for higher NRM with increasing donor age, though a significant reduced risk of disease relapse and improved progression-free survival (PFS) was associated with older donors. Donor/recipient kinship, especially maternal donors, predicted worse PFS and OS. $^{41}$

\section{Donor Gender}

Female donor T-cells recognizing minor histocompatibility antigens (mHAgs) encoded on the male $\mathrm{Y}$ chromosome (H-Y) have been hypothesized to induce GvHD and therefore cause increased NRM in a male recipient/female donor setting. As H-Y antigens can also be expressed on leukemic blasts, the primary negative circumstance could be highly beneficial for GvL and therefore lower the risk of relapse. This effect plays an important part especially in HLA-matched transplantations, where mHAgs are the only target structures for alloreactive T-cells. ${ }^{42,43}$ By contrast, considering that haploHCT male donors should be preferred for male recipients, as female donors for male recipients are associated 
with inferior survival. ${ }^{31}$ In addition, compared to nulliparous female and male donors, transplantation from parous female donors is associated with a higher NRM because of GvHD. ${ }^{36}$

\section{Stem Cell Source}

Filgrastim-mobilized peripheral blood stem cells (PBSCs) have become the main source of donor stem cells for related and unrelated alloHCT. ${ }^{44}$ They have been associated with beneficial events such as early engraftment and lower incidence of graft failure compared with bone marrow stem cells (BMSCs), but also induce significantly higher rates of acute and chronic GvHD related to T-cell repleted PBSC allografts. ${ }^{45}$ Still, these T-cell-rich grafts offer a significant GvL potential to confer increased leukemia-free survival (LFS) and OS despite elevated risk of TRM. ${ }^{46}$ Especially, in the setting of reduced intensity conditioning (RIC), PBSCs mediate anti-leukemic effects, thus resulting in superior survival and significantly decreased risk of relapse with no difference in NRM compared with BMSCs. ${ }^{47}$ However, the increased risk of acute and/or chronic GvHD after peripheral blood grafts needs to be clinically and scientifically addressed in further investigations improving GvHD prophylaxis without nullifying GvL to reduce late morbidity and mortality and achieve long-term LFS and cure, respectively. Recently, interesting data have revealed a modified allograft composition when additionally mobilized with plerixafor (AMD3100). An increase in the total number of nucleated cells, including CD4+ and CD8+ T-cells, as well as regulatory T-cells (Tregs), CD19+ B-cells, plasmacytoid dendritic cells (DCs) and primitive immature CD34 +CD38-CD133+ progenitor cells harboring high selfrenewal potential were detected in grafts mobilized with G-CSF and plerixafor. ${ }^{48,49}$ Studies have also demonstrated the beneficial effects of Tregs in the alloHCT setting concerning improved OS, lower rates of acute GvHD, and GvL preservation. ${ }^{49-51}$ Nonetheless, further immunologic pathways apart from cellular components might be initiated, as plerixafor preferentially mobilizes a plasmacytoid DC precursor that produces high interferon- $\alpha($ IFN- $\alpha)$ levels and a favorable balance of immune effectors that lowers the risk of GvHD. ${ }^{49,52}$

\section{Disease Status Prior to Transplant}

To achieve long-term survival in AML patients after alloHCT, maximum reduction of leukemic burden prior to transplant is essential for outcome. Patients with an uncontrolled and active disease status as well as patients in morphologic complete remission (CR), but who still show measurable residual disease (MRD), are at increased risk for relapse and are likely to have a short OS. ${ }^{53-56}$ To determine MRD, cytogenetic testing is established in everyday routine, whereas the value of MRD detection through next-generation sequencing has yet to be evaluated and flow-cytometry-based MRD needs to be harmonized. ${ }^{57,58}$ A way to counteract the disadvantage of persistent disease or MRD, respectively, and to minimize pretransplant tumor burden is the application of sequential or intensified conditioning such as melphalan, intensified busulfan, high-dose cyclophosphamide, or TBI-based regimens. ${ }^{59-64}$ However, trying to achieve MRD negativity by additional therapies or salvage treatments before alloHCT also contributes to increased toxicity and selection or development of highly resistant leukemic clones and altogether postpones application of alloreactive antileukemic CD8+ T-cells and therefore delays the inevitable effect of GvL for high-risk AMLs. The question of the ideal point of time when to transplant is an objective of ongoing trials (NCT02461537). ${ }^{65}$

\section{Conditioning Regime}

As early as the 1990s, intensive myeloablative conditioning (MAC) regimens have been associated with reduced risk of relapse. ${ }^{66}$ Especially, in the matched-sibling setting, retrospective data showed a superior benefit concerning relapse in MAC conditioning compared with RIC. ${ }^{67,68}$ However, the use of myeloablative alloHCT is limited because of organ toxicities. The advent of RIC regimens has both broadened the spectrum of patients being eligible for transplant and decreased the toxicity and TRM of myeloablative alloHCT. ${ }^{69}$ Moreover, emerging evidence presents that in case of good response after induction therapy, RIC and MAC protocols are equally effective in terms of OS, with a tendential benefit for RIC regarding reduced TRM, though RIC presents with a significantly higher rate of relapse than MAC in prospective trials $(\mathrm{p}<$ 0.01)..$^{20,70,71}$ Consequently, MAC should be considered whenever possible, and conditioning dose intensification should be applied if physically feasible. Furthermore, sequential application of potentially toxic conditioning components (eg, melphalan and fludarabine/TBI) is thought to generate moderated toxicity. Recently, conditioning regimens are increasingly personalized to optimize transplant outcomes. For patients requiring RIC, an underlying key tool for acceptable relapse rates and long-term 
survival is attributed to a potent GvL effect, which made the usage of less intense conditioning and achieving of satisfying results possible. Notably, especially, in the setting of RIC alloHCT, robust GvL effect and chronic GvHD are strongly intrinsically connected processes, challenging treating physicians in the posttransplant followup. $^{72}$

\section{GvHD and GvHD Prophylaxis}

Withdrawal of immunosuppression has been one of the simplest and well-studied interventions to prevent imminent relapse and give way to stronger GvL over the last years. ${ }^{73}$ Still, development of GvHD often hampers rapid tapering of immunosuppression. GvHD is one of the most dreaded complications after alloHCT. ${ }^{74}$ Recognition of major and minor histocompatibility antigens expressed in patients' non-hematologic tissues by stimulated donorderived T-cells can lead to acute and/or chronic GvHD, a relevant number of patients even have to face a lethal course. The greater the disparity between donor and recipient's HLA matching, the higher the risk of GvHD development. Tissue damage caused by conditioning, especially MAC regimens, can further trigger GvHD. ${ }^{75}$ The yet unresolved crux of this therapeutic challenge is the interdependency of GvHD and GvL, as they are mediated by the same CD8+ T-cells. ${ }^{76}$ GvHD has a protective potential regarding disease reoccurrence. Still, evidence reveals that these two phenomena are characterized by individual and differential pathophysiologic pathways, which could potentially give way to new therapeutic strategies, shifting posttransplant T-cell reconstitution from GvHD to an intensified GvL activity, therefore refining GvHD prophylaxis while leaving GvL unaffected. ${ }^{25}$

The introduction of PtCy launched a whole new era of T-cell-replete alloHCT differing an entire HLA haplotype between donor and recipient with satisfying rates of engraftment, OS, EFS, NRM, and acute and chronic GvHD, thus expanding donor availability for a considerable number of patients lacking a related or unrelated matched donor who would otherwise have no option for curative treatment. ${ }^{77-81}$ Preclinical studies have provided evidence of CD4+FOXP3+ Tregs as the key essential effectors of alloimmune regulation after PtCy application. ${ }^{82,83}$ Tregs mitigate GvHD while preserving GvL. Therefore, it is an attractive alternative and revolutionary GvHD prophylaxis option in contrast to conventional pharmacologic immunosuppression (eg, anti-thymocyte globulin, calcineurin inhibitors, and methotrexate) yielding singularly on the depletion of donor alloreactive T-cells and therefore potentially minimizing GvL. Another approach beyond pharmacological immunosuppression to support GvL strengthening is the infusion of adoptive FOXP3+ Tregs or regulatory Type $1 \mathrm{~T}$-cells posttransplant or graft manipulation such as selective depletion of alloreactive T-cells. ${ }^{84,85}$

Recently, adoptive T-cell therapy applications in the context of GvHD prophylaxes while augmenting GvL were brought into focus. Several active Phase 1 and/or Phase 2 GvHD prophylaxis studies (eg, NCT04678401, NCT01660607, and NCT03977103) aim to determine the safety, feasibility, and efficacy of immunosuppression-free strategies by infusion of T-cell repleted grafts, followed by T-cell add back of donor Tregs and conventional T-cells (Tcons) in a matched or haploidentical setting, respectively. Additionally, by achieving effective prevention of severe GvHD and long-term tolerance, subsequent and rapid tapering and discontinuation of immunosuppressive medication will strongly give rise to $\mathrm{CD} 8+$ donor-derived T-cells, prompting necessary anti-leukemic potential and important anti-infectious functions. ${ }^{86,87}$

\section{T-Cell Alloreactivity and T-Cell Subpopulations}

A generally accepted consensus in the transplantation area is that alloreactive CD4+ and CD8+ T-cells are the central and primary mediators of a powerful GvL and that cell recognition of recipients' mHAgs is mainly the effector mechanism of T-cell response in many hematologic entities. A dreaded parallel event is the manifestation of GvHD mediated by the same effector cells, especially $\alpha \beta$ T-cells, while innate-like $\gamma \delta$ T-cells are supposed to exert an anti-leukemic effect without inducing GvHD. ${ }^{88}$ Hence, several approaches of (selective) $\alpha \beta$ T-cell depletion have been pursued, unfortunately resulting in increased risk of graft failure and relapse. ${ }^{89,90}$ To partially compensate this downside of total T-cell depletion, T-cell add back by infusing either Tcons, Tregs, or donor-specific T-cells equipped with a suicide gene has been investigated to shift the alloreactive power back to GvL. ${ }^{91,92}$

Although associated with higher rates of NRM, posttransplant CMV replication and infection have been repeatedly reported to correlate with a lower risk of leukemic relapse. ${ }^{93,94}$ Matching a CMV-positive donor to a CMVpositive recipient has shown to improve outcomes after MAC. ${ }^{95}$ This beneficial aspect might be due to the expansion of donor-derived $\mathrm{V} \delta 2^{\text {neg } \gamma \delta} \mathrm{T}$-cells, though their target antigens are still not completely identified. ${ }^{94}$ Another possible 
immunologic explanation of this observation is an increased expression of HLA-C on CD56-CD16+ NK cells and a higher number of killer immunoglobulin-like receptors (KIRs), CD56, CD57, and NKG2C coexpressing CD8+ T-cells in CMV-positive alloHCT recipients, leading to the regulation of KIR expression and interaction with HLA-C by proliferating CMV-specific CD8+ T-cells, which eventually might contribute to GvL effects posttransplant. ${ }^{96}$ Worth mentioning are conflicting results demonstrating that donor CMV serostatus after T-cell replete haploHCT has no effect on NRM or OS, making it difficult to determine CMVdependent donor preferences in this setting. ${ }^{97}$

Studies investigating the T-cell receptor (TCR) repertoire are expected to add further knowledge for clinical applications. Interestingly, existing data indicate a correlation between advanced diversity in the TCR repertoire early after alloHCT and certain T-cell subclones with a lower risk of relapse and less GvHD. ${ }^{98}$ Noticeably, at the time of AML relapse, upregulation of inhibitory TCRs mirror alterations of leukemic blasts expressing the respective ligands. Furthermore, exhausted T-cells display a restricted TCR repertoire and are detectable months before relapse. ${ }^{99}$ Therefore, the expression of T-cell exhaustion markers could be used as predictive indicators for guidance of preemptive therapies.

\section{DLIs}

Continuous posttransplant monitoring is crucial for rapidly detecting imminent relapse and, by utilizing specific relapse treatments, improving OS. Following routine MRD diagnostics, measurement of donor-specific chimerism (or, if available, CD34+ subset chimerism) is a standard practice for disease monitoring and evaluation of donor engraftment after alloHCT. In case of imminent relapse or low leukemic burden, administration of DLIs is a simple and feasible means to reinforce GvL yielding a polyclonal T-cell response and to improve survival, especially in high-risk AML. ${ }^{13,100,101}$ Unfortunately, DLIs are ineffective in overt morphologic leukemia relapse, allocating a tight time frame for clinical use. ${ }^{13,100}$ Still, one of the major pitfalls is triggering GvHD. The incorporation of suicide genes and transfusion of T-cell subsets without alloreactivity have tried to circumvent this potentially fatal complication. ${ }^{102-104}$ After haploHCT with PtCy, administration of escalating doses of haplo DLIs showed a satisfying rate of CR with acceptable rates of acute GvHD without cases of severe or chronic GvHD. ${ }^{105}$ The combination of DLIs with hypomethylating agents (HMAs) has been associated with increased susceptibility of leukemic clones to the applied treatment and demonstrated effectiveness particularly in AML with low disease activity at the time of relapse. $^{106}$

Future studies will reveal whether other T-cell based antigen-targeted therapies such as CAR-T-cells can improve therapeutic response to salvage therapy and improve survival in relapsed/refractory AML ( $\mathrm{r} / \mathrm{r}$ AML).

\section{NK Cells and KIR Receptors}

A growing body of evidence illuminates further mediators in the process of alloreactivity. NK cells and KIRmediated alloreactive effects via epitopes presented by HLA class I molecules gain an increasing role in new therapeutic approaches reinforcing the GvL effect in preemptive strategies or once relapse has occurred. The balance between inhibitory and activating signals is crucial for the physiological function of NK cells. Interactions with HLA class I molecules trigger inhibitory signals, protecting cells from NK cell lysis. Inhibitory KIR receptors play a major role for NK cell activity. Similar to HLA, KIR genes are highly polymorphic sites with a variable number of KIR genes, coding for either activating or inhibitory cell-surface receptor activity. NK cells with a KIR-ligand mismatch, especially the KIR B haplotype $(\mathrm{B} / \mathrm{x})$, demonstrate a strong alloreactive potential without inducing GvHD. ${ }^{107,108}$ Again, in the haploidentical setting, donor KIR B haplotype could be associated with a significantly reduced risk of relapse and NRM. ${ }^{109,110}$ Later, the concept of "missing self" was introduced, providing a more veritable model of KIR interaction with recipients' KIR ligands. ${ }^{111}$ Especially ligand incompatibility between donor and recipient in KIR3DL1 recognizing the HLA-Bw4 group, KIR2DL2 and KIR2DL3 recognizing the HLA-C1 group, and KIR2DL1 recognizing the HLA-C2 group in haploHCT could be associated with increased GvL effects and significantly lower rates of relapse in AML. ${ }^{112}$ Recently, the beneficial effect of haplo NK cells has been shown particularly in T-cell repleted grafts. ${ }^{113}$ Therefore, in addition to comprehensive HLA typing, KIR sequencing and KIR genotypes should be further investigated regarding their impact in alloHCT and whether they can be implemented in the future by selecting donors with favorable KIR genotypes in KIRmismatched transplantation for improving outcome for AML patients undergoing alloHCT. 
Missing inhibitory ligands activate NK cytotoxicity. NKG2D that binds to major histocompatibility complex class I chain-related protein A and B (MIC A and MIC B) and UL16 binding proteins (ULBPs) is an important activating receptor expressed by NK cells and cytotoxic T-cells alike. ${ }^{114}$ The fact that leukemic stem cells often lack NKG2D activating ligands is a perfect example of leukemic immune evasion from NK and, after alloHCT, alloreactive surveillance. ${ }^{115} \mathrm{~A}$ similar mechanism has been attributed to decreased expression of cytotoxic receptor DNAM-1 on NK cells in AML patients. ${ }^{116}$ NK cell dysfunction investigated in AML patients has been detected in almost all patients at first diagnosis. ${ }^{117}$ Among the underlying mechanisms are decrease or loss of activating natural cytotoxicity receptor (NCR) expression via direct cell-cell contact between leukemic blasts and NK cells or via cytokine-dependent NCR downregulation or NK stimulation. ${ }^{117,118} \mathrm{CMV}$-mediated expansion of donorderived NKG2C + NK cells recognizing HLA-E of residual leukemic blasts and/or the lack of HLA molecules according to the missing self-theory have been hypothesized to be beneficial for reducing rate of disease relapse. ${ }^{119}$

Data suggest that GvL mediated by NK cells may be initiated immediately once the donor graft is transfused. ${ }^{120}$ In a previous study, relapse rates were decreased in a subcohort that was characterized by higher numbers of NK cells within the graft than the median cohort NK-cell number when compared with another subgroup with NK cell numbers below the median value ( $5 \%$ vs $43 \%) .{ }^{121}$ Consistently, high numbers of NK cells early after alloHCT provide potential GvL effect via NK cell alloreactivity demonstrated by lower relapse rates and increased survival. ${ }^{122}$ The NK cell GvL effect may be a powerful tool for enhancing the efficacy and safety of allogeneic hematopoietic transplantation without the risk of GvHD. However, further knowledge about NK cell education and the T-cell interplay is needed to provide safe clinical use.

\section{Microenvironment}

As primarily described in solid tumors, alterations in the microenvironmental composition induced by malignant cells gain increasing importance in the field of hematologic neoplasms and add an additional level of complexity in the understanding of relapse biology. Several investigations have demonstrated the potential of leukemic blasts to optimize immune tolerance by influencing physiological mechanisms of the bone marrow niche favoring their own survival benefit. ${ }^{123}$ This immune evasion is achieved by several modifications of both host and donor components. One of the best described pathways of tumor extrinsic immune modulation is a modification of the leukemic microenvironment by a deregulated release of cytokines by residual leukemic blasts. This process includes a limited production of interferon- $\gamma$ (IFN- $\gamma)$, interleukin 15 (IL-15), or G-CSF during leukemic transformation or an accelerated release of IL-10 and transforming growth factor beta (TGF- $\beta$ ), shifting the surrounding niche from a proinflammatory and therefore immunogenic environment into an immunosuppressive milieu and finally evading effector T- and NK cell mediated GvL. IL-15 occupies a special role in cytokine composition of the bone marrow niche, which is physiologically produced by DCs. ${ }^{124} \mathrm{IL}-15$ has an activating function concerning T-cell and NK cell function and expansion and further leads to the creation of memory T-cells. ${ }^{125}$ Consequently, low levels of IL-15 appear to be a predictive marker of relapse posttransplant, and maintenance therapies aiming for IL-15 induction have been established in the clinical routine for certain AML subgroups. ${ }^{126,127}$ Further metabolites such as indoleamine 2,3-dioxygenase-1 (IDO1) or amino acid arginase (Arg) expressed by leukemic blasts or immunoregulatory DC, respectively, significantly interfere with immunomodulatory pathways within the niche. This comprises inhibition of T-cell activity and function while inducing Treg expansion (IDO1), causing further effector T-cell anergy, or stimulating phenotypic changes of macrophage populations from proinflammatory M1 to immunosuppressive M2 phenotype (Arg). ${ }^{128,129}$ In addition, extracellular adenosine generated by ectonucleotidases CD39 and CD73 expressed on leukemic blasts bind to adenosine receptor $A_{2 A}$ $\left(\mathrm{A}_{2 \mathrm{~A}} \mathrm{AR}\right)$ and thereby promote suppression of antileukemic T- and NK cell function. ${ }^{130-132}$ Recently, murine models explored the interdependency between leukemiaderived lactic acid and hampered T-cell glycolysis and IFN- $\gamma$ production; surprisingly the detrimental effect of lactic acid was reversed by sodium bicarbonate, reestablishing GvL in human and murine T-cells and restoring IFN- $\gamma$ production. ${ }^{133}$

\section{Leukemia-Specific Characteristics and Immune Evasion}

Although the majority of AML relapse after alloHCT occurs within the first 12 months, approximately $15 \%$ of patients present with a late relapse. ${ }^{134}$ Favoring escape 
from $\mathrm{GvL}$ as an evolutionary process, gain of adverse-risk mutations, development of immune resistance mechanisms, expression of inhibitory ligands, or downregulation of target molecules are found frequently during leukemic relapse. Interestingly, a considerable number of AML patients acquire immune evasion mechanisms during leukemic evolution, which further highlights the importance of $\mathrm{GvL}$ for tumor control.

\section{HLA Loss}

The abrogation of T-cell mediated anti-leukemic interactions by alterations in the expression and functionality of HLA classes I and II in hematologic diseases after alloHCT has revolutionized our knowledge of relapse characteristics. In 2009, Vago et al demonstrated an acquired uniparental disomy (aUPD) of chromosome 6p by copy-neutral loss of heterozygosity in the HLA locus (HLA loss) after haploHCT in one-third of relapsed cases. ${ }^{135}$ For the MMUD setting, HLA loss is observed in about $5-25 \%$ of cases; after MUD transplantation, HLA loss has been detected in approximately $15 \%$ of relapsed cases, and reports have demonstrated cases of HLA loss after MSD transplantation. ${ }^{134,136,137}$ By contrast, at the time of AML diagnosis, this phenomenon is very uncommon. ${ }^{138,139}$ Compared with "classic" AML relapses, HLA loss relapse occurs significantly later and is associated with active disease at transplant, which stresses the importance of low or negative MRD before alloHCT. ${ }^{140}$ Moreover, HLA loss appears to occur less often in T-cell depleted haploidentical grafts, and larger studies need to investigate this aspect. Further analysis should also focus on the question whether certain HLA loci are more prone to HLA loss than others.

Through fundamental genomic loss of the mismatched patient-specific HLA haplotype and its replacement with the homologous copy, leukemic blasts lose their immunodominant and crucial GvL target, escaping immunologic pressure and becoming "invisible" for alloreactive T-cells. As a "proof of principle", the application of DLIs becomes ineffective while preserving their risk of GvHD. From a translational view, the inability of some NK cells to recognize HLA loss despite the frequent loss of HLA alleles that also represent inhibitory KIR ligands, is still undergoing intensive research. ${ }^{141}$ Second allogeneic transplantation with a donor favorably expressing the complementary haplotype and therefore possibly intensifying GvL, adoptive and designed NK-based treatments or nonHLA restricted immunotherapies such as CAR-T-cells or bispecific antibodies redirecting T-cell and/or NK cell response (eg, CD3 for T-cells and CD16 for NK cells targeting leukemic CD33) are possible salvage options in case of HLA loss relapse. ${ }^{142-144}$

Another HLA alteration by epigenetic downregulation of HLA class II molecules through a downregulated major histocompatibility class II transactivator (CIITA) has been identified, translating into a lack of recognition of affected leukemic blasts by CD4+ T-cells and therefore compromising GvL. Likewise, higher counts of T-cells infused with the graft were associated with a higher chance of HLA II downregulation, though the frequencies of HLA II downregulation were similar in matched and unmatched donors, suggesting that alloreactivity is directed mostly against other antigens (eg, mHAgs). ${ }^{145,146}$ High levels of IFN- $\gamma$ induced by T-cell cross-recognition restituted expression of downregulated HLA class II molecules and eradicated relapse by reestablishing GvL, therefore making IFN- $\gamma$ an attractive object of future studies and therapeutic approaches and implying a beneficial aspect of a proinflammatory environment as seen in GvHD. ${ }^{145}$ Still, the side effects of proinflammatory molecules secreted in the leukemic microenvironment, such as IFN$\gamma$, which is also a potential driver for upregulation of inhibitory ligands like programmed death-1 ligand (PDL1) and thus favoring immune escape, need to be considered.

\section{Immune Checkpoint Alterations}

In addition to HLA-dependent immune evasion mechanisms, multiple inhibitor molecules impairing T-cell responses after alloHCT have been revealed over the last years. Recently, inhibitory ligands have been found to be increasingly expressed in up to $40 \%$ of relapse cases. ${ }^{145}$ The interaction of T-cell inhibitory ligands such as PD-L1 or cytotoxic T-lymphocyte-associated protein 4 (CTLA-4) with the respective TCR effectively abrogates the cytotoxic function and proliferation of alloreactive T-cells, thus mitigating or nullifying GvL and finally generating T-cell exhaustion. ${ }^{147}$ New immunotherapeutic methods are needed to conquer these highly aggressive immune escape mechanisms. For example, the use of monoclonal PD-L1 antibodies such as nivolumab for leukemic blasts overexpressing PD-L1 or monoclonal antibodies like ipilimumab targeting the CTLA-4/B7 axis partially restored antileukemic T-cell functions. ${ }^{148-150}$ However, inhibitory ligand expression is characterized by a high inter-patient variability, and shared regulatory pathways should be 
identified and therapeutically addressed. Also, the development of acute GvHD during immune checkpoint inhibitor therapy should be taken seriously and monitored precisely. ${ }^{151}$ Furthermore, combinatory therapies including HMAs and immune checkpoint blockade deliver promising results. $^{152,153}$ Ongoing studies (eg, NCT02890329, NCT02845297) are investigating the combination of immune checkpoint inhibitors and HMAs in the posttransplant setting. These observations might translate into clinical practice to either prevent imminent relapse or to offer potent relapse strategies, as uncontrolled r/r AML is associated with a very poor prognosis and a short survival.

\section{Tumor-Specific Antigens (TSAs)}

So far, AML patients have not benefited from recent achievements in immunotherapeutic approaches compared with patients having solid cancer. This is mostly due to the lack of targetable leukemic-specific immunogenic ligands. To date, the frequency of newly acquired inhibitory molecules is also difficult to reveal because of the complex expression patterns and the generally low expression at baseline. ${ }^{154}$ Lately, encouraging studies investigating the proteogenomic features of HLA class I molecules of AML patients have shown that leukemic blasts and stem cells express TSAs. These antigens represent strong targets for GvL, as they demonstrated elicitation of CD8+ T-cells in vivo and in vitro and improved survival. Astonishingly, TSA are mostly seen in intronic and therefore non-coding genomic regions and may be intrinsic predictors for sufficient GvL. Intron retention and epigenetic modulations are supposed to be essential for TSA biology, as epigenetic modifiers such as DNMT3A mutations correlated with TSA RNA expression. ${ }^{155}$ These data stimulate further detailed analysis of immunopeptidomes in AML patients and may offer chances to break new grounds in AML immunotherapy.

\section{Maintenance Therapy for AML After alloHCT}

Disease relapse occurs in approximately $40 \%$ of patients with AML after transplantation and is the main cause of death. ${ }^{11}$ The success of salvage treatments is aggravated by the fact that AML is a biologically heterogenous and aggressive disease and presents with various relapse mechanisms. ${ }^{156}$ Considering the very poor prognosis in relapse cases, preventive strategies are highly desirable to improve outcome. Maintenance therapies have therefore become a popular means to maintain disease control or prolong DFS. Targeted therapies with regard to the clonal landscape of leukemic stem cells have been a clinically favored option for patients with AML harboring molecular targets. Tyrosine kinase receptor inhibitors are probably the most established form of targeted therapy in AML and other malignant entities. ${ }^{157,158}$ One important representative of alterations in tyrosine kinase receptor genes are Fms-related tyrosine kinase 3 (FLT3) mutations, which are frequently mutated in AML and simultaneously define worse prognosis because of frequent relapse. ${ }^{159}$ Therefore, multiple inhibitory molecules for FLT3-internal tandem duplication (ITD) and FLT3-tyrosine kinase domain (TKD) have been developed and successfully implemented in daily practice. ${ }^{160-162}$ Sorafenib plays a pivotal role in the maintenance of FLT3-ITD-mutated AML after alloHCT, demonstrating improved outcomes after alloHCT based on a significantly reduced risk of relapse. ${ }^{127}$ Additional immune-mediated efficacy of sorafenib, as well as tyrosine kinase inhibitors tandutinib, midostaurin, crenolanib, and quizartinib has been attributed to enhanced IL-15 transcription in FLT3-ITD-positive leukemic clones, leading to increased anti-leukemic CD8 $+\mathrm{CD} 107 \mathrm{a}+\mathrm{IFN}-\gamma+\mathrm{T}$-cell counts and consequently intensified GvL effect. ${ }^{118} \mathrm{NK}$ cells are another cellular profiteer of elevated IL-15 levels, increasing their anti-leukemic activity and equipping sorafenib a broader spectrum of action than just solely targeting FLT3-ITD mutations. Further results of studies investigating the potential of gilteritinib as FLT3-ITD inhibitor maintenance after alloHCT are eagerly awaited and could add further therapeutic players for GvL (NCT02997202).

Regarding other molecular AML entities (eg, IDH1, $I D H 2, \quad R U N X 1$, and EZH2) and, in times of highthroughput panel sequencing, other emerging targetable structures (eg, $C D K 9$, and $B T K$ ), respectively, innovative therapeutic approaches are gaining increasing clinical interest and scientific focus, either as a single agent or as combinational therapy. However, most of them are investigated in preclinical models and have not been applied in clinical posttransplant settings yet. ${ }^{163-167}$

Pharmacological strategies modifying GvL after transplant have been introduced by implementation of HMAs like azacitidine or decitabine. In addition to the inhibition of DNA methyltransferases, these agents upregulate leukemia-associated antigens (eg, PRAME and MAGE-A), mHAgs, HLA class I and II molecules, costimulatory molecules such as ULBPs and MIC A and an intensified 
CD8+ T-cell response, hereby augmenting GvL. ${ }^{143,168-170}$ Furthermore, azacitidine stimulates the conversion of CD4 +CD25- T-cells into Tregs by inducing FOXP3 expression both in vitro and in vivo and expand the total number of Tregs. ${ }^{170,171}$ By contrast, HMA-associated upregulation of inhibitory molecules on the leukemic surface and therefore inhibition of GvL are raising the question of combined approaches in the case of relapse. ${ }^{172}$

\section{Conclusions}

Grand strides in performing alloHCT have enabled physicians worldwide to offer alloHCT for nearly all eligible AML patients. However, enhancing an enduring GvL effect to efficiently control AML relapse is still an immunomodulatory and therapeutic challenge in the context of therapy-related toxicity and GvHD. Based on the compiled knowledge obtained in numerous trials in the last decades, MAC regimens should be applied for high-risk AMLs and MRD positivity whenever possible. If RIC is required, PBSC grafts are recommended over BMSC grafts because of longer OS and lower risk of relapse.

Donor age becomes an increasingly significant characteristic in the process of donor selection. HLA disparity is still a key selection criterion, but new knowledge about the effect of small nucleotide variants, HLA subgroups, and NK cells/KIRs will broaden our perspective and influence our decision for choosing "the donor". T-cells and their respective sub-entities play the main part for therapy success or failure. New therapeutic approaches, such as NK cell infusion during transplant, or immunomodulatory molecules have to be defined and evaluated in prospective trials. The role of PtCy beyond the haploidentical donor setting and its combination with RIC protocols will be one of the most attractive foci of future clinical trials. The underlying mechanisms differentiating alloreactive processes and processes inducing tolerance are still insufficiently understood and need to be intensively investigated. Deciphering AML relapse mechanisms provides an opportunity to develop and utilize targeted therapies either in the induction or maintenance therapy and thus to either achieve MRD negativity before transplant or to augment GvL by lowering the leukemic burden. Regardless which component will be the most effective to induce and maintain GvL, GvL is the key tool to achieve long-term survival and cure for patients with AML.

\section{Disclosure}

The authors report no conflicts of interest for this work.

\section{References}

1. Passweg JR, Baldomero H, Bader P, et al.; for the European Society for Blood and Marrow Transplantation (EBMT). Hematopoietic stem cell transplantation in Europe 2014: more than 40000 transplants annually. Bone Marrow Transplant. 2016;51(6):786-792. doi:10.1038/bmt.2016.20.

2. Cornelissen JJ, Gratwohl A, Schlenk RF, et al. The European LeukemiaNet AML Working Party consensus statement on allogeneic HSCT for patients with AML in remission: an integrated-risk adapted approach. Nat Rev Clin Oncol. 2012;9 (10):579-590. doi:10.1038/nrclinonc.2012.150

3. Koreth J, Schlenk R, Kopecky KJ, et al. Allogeneic stem cell transplantation for acute myeloid leukemia in first complete remission: systematic review and meta-analysis of prospective clinical trials. JAMA. 2009;301(22):2349-2361. doi:10.1001/jama.2009.813

4. Passweg JR, Baldomero H, Bader P, et al.; for the European Society for Blood and Marrow Transplantation (EBMT). Is the use of unrelated donor transplantation leveling off in Europe? The 2016 European Society for Blood and Marrow Transplant activity survey report. Bone Marrow Transplant. 2018;53(9):1139-1148. doi:10.1038/s41409-018-0153-1.

5. Duarte RF, Labopin M, Bader P, et al.; for the European Society for Blood and Marrow Transplantation (EBMT). Indications for haematopoietic stem cell transplantation for haematological diseases, solid tumours and immune disorders: current practice in Europe, 2019. Bone Marrow Transplant. 2019;54(10):1525-1552. doi:10.1038/s41409-019-0516-2.

6. Döhner H, Estey E, Grimwade D, et al. Diagnosis and management of AML in adults: 2017 ELN recommendations from an international expert panel. Blood. 2017;129(4):424-447. doi:10.1182/blood-2016-08-733196

7. Stölzel F, Platzbecker U, Mohr B, et al. Early intervention with allogeneic hematopoietic cell transplantation during chemotherapy-induced aplasia in patients with high-risk acute myeloid leukemia. Leukemia. 2013;27(10):2068-2072. doi:10.1038/leu.2013.142

8. Middeke JM, Herbst R, Parmentier S, et al.; for the Study Alliance Leukemia (SAL). Clofarabine salvage therapy before allogeneic hematopoietic stem cell transplantation in patients with relapsed or refractory AML: results of the BRIDGE trial. Leukemia. 2016;30(2):261-267. doi:10.1038/leu.2015.226.

9. de Lima M, Porter DL, Battiwalla M, et al. Proceedings from the National Cancer Institute's Second International Workshop on the biology, prevention, and treatment of relapse after hematopoietic stem cell transplantation: part III. Prevention and treatment of relapse after allogeneic transplantation. Biol Blood Marrow Transplant. 2014;20(1):4-13. doi:10.1016/j.bbmt.2013.08.012

10. Horowitz M, Schreiber H, Elder A, et al. Epidemiology and biology of relapse after stem cell transplantation. Bone Marrow Transplant. 2018;53(11):1379-1389. doi:10.1038/s41409-018-0171-z

11. Bejanyan N, Weisdorf DJ, Logan BR, et al. Survival of patients with acute myeloid leukemia relapsing after allogeneic hematopoietic cell transplantation: a center for international blood and marrow transplant research study. Biol Blood Marrow Transplant. 2015;21(3):454-459. doi:10.1016/j.bbmt.2014.11.007

12. Schmid C, Labopin M, Nagler A, et al. Treatment, risk factors, and outcome of adults with relapsed AML after reduced intensity conditioning for allogeneic stem cell transplantation. Blood. 2012;119(6):1599-1606. doi:10.1182/blood-2011-08-375840

13. Schmid C, Labopin M, Nagler A, et al. Donor lymphocyte infusion in the treatment of first hematological relapse after allogeneic stem-cell transplantation in adults with acute myeloid leukemia: a retrospective risk factors analysis and comparison with other strategies by the EBMT acute leukemia working party. $J$ Clin Oncol. 2007;25(31):4938-4945. doi:10.1200/JCO.2007.11.6053 
14. Christopeit M, Kuss O, Finke J, et al. Second allograft for hematologic relapse of acute leukemia after first allogeneic stem-cell transplantation from related and unrelated donors: the role of donor change. J Clin Oncol. 2013;31(26):3259-3271. doi:10.1200/JCO.2012.44.7961

15. Lee CJ, Savani BN, Mohty M, et al. Post-remission strategies for the prevention of relapse following allogeneic hematopoietic cell transplantation for high-risk acute myeloid leukemia: expert review from the Acute Leukemia Working Party of the European Society for Blood and Marrow Transplantation. Bone Marrow Transplant. 2019;54(4):519-530. doi:10.1038/s41409018-0286-2

16. Rautenberg C, Germing U, Haas R, Kobbe G, Schroeder T. Relapse of acute myeloid leukemia after allogeneic stem cell transplantation: prevention, detection, and treatment. Int $\mathrm{J} \mathrm{Mol}$ Sci. 2019;20(1):228. doi:10.3390/ijms20010228

17. Horowitz MM, Gale R, Sondel PM, et al. Graft-versus-leukemia reactions after bone marrow transplantation. Blood. 1990;75:555-562. doi:10.1182/blood.V75.3.555.bloodjournal753555

18. Weiden PL, Sullivan KM, Flournoy N, Storb R, Thomas ED. Antileukemic effect of chronic graft-versus-host disease. $N$ Engl $J$ Med. 1981;304(25):1529-1533. doi:10.1056/NEJM198106183 042507

19. Butturini A, Bortin M, Gale R. Graft-versus-leukemia following bone marrow transplantation. Bone Marrow Transplant. 1987;2 (3):233-242.

20. Bornhäuser M, Kienast J, Trenschel R, et al. Reduced-intensity conditioning versus standard conditioning before allogeneic haemopoietic cell transplantation in patients with acute myeloid leukaemia in first complete remission: a prospective, open-label randomised phase 3 trial. Lancet Oncol. 2012;13(10):1035-1044. doi:10.1016/S1470-2045(12)70349-2

21. Beelen DW, Trenschel R, Stelljes M, et al. Treosulfan or busulfan plus fludarabine as conditioning treatment before allogeneic haemopoietic stem cell transplantation for older patients with acute myeloid leukaemia or myelodysplastic syndrome (MC-FludT.14/ L): a randomised, non-inferiority, phase 3 trial. Lancet Haematol. 2020;7(1):e28-e39. doi:10.1016/S2352-3026(19)30157-7

22. Ringdén O, Boumendil A, Labopin M, et al. Outcome of allogeneic hematopoietic stem cell transplantation in patients age $>69$ years with acute myelogenous leukemia: on behalf of the acute leukemia working party of the European society for blood and marrow transplantation. Biol Blood Marrow Transplant. 2019;25 (10):1975-1983. doi:10.1016/j.bbmt.2019.05.037

23. Li J-M, Giver CR, Lu Y, Hossain MS, Akhtari M, Waller K. Separating graft-versus-leukemia from graft-versus-host disease in allogeneic hematopoietic stem cell transplantation. Immunotherapy. 2010;34:599-621.

24. Warren EH, Deeg HJ. Dissecting graft-versus-leukemia from graft-versus-host-disease using novel strategies: dissecting GVL from GVHD. Tissue Antigens. 2013;81(4):183-193. doi:10.1111/ $\tan .12090$

25. Negrin RS. Graft-versus-host disease versus graft-versusleukemia. Hematology. 2015;2015(1):225-230. doi:10.1182/asheducation-2015.1.225

26. Chang Y-J, Zhao X-Y, Huang X-J. Strategies for enhancing and preserving anti-leukemia effects without aggravating graft-versushost disease. Front Immunol. 2018;9:3041. doi:10.3389/ fimmu.2018.03041

27. Robinson J, Halliwell JA, Hayhurst JD, et al. IMGT/HLA database: allele variant databases. Nucleic Acids Res. 2015;43(D1): D423-D431. doi:10.1093/nar/gku1161
28. Anasetti C, Beatty PG, Storb R, et al. Effect of HLA incompatibility on graft-versus-host disease, relapse, and survival after marrow transplantation for patients with leukemia or lymphoma. Hum Immunol. 1990;29(2):79-91. doi:10.1016/0198-8859(90) 90071-V

29. Ayuk F, Beelen DW, Bornhäuser M, et al. Relative impact of HLA matching and non-HLA donor characteristics on outcomes of allogeneic stem cell transplantation for acute myeloid leukemia and myelodysplastic syndrome. Biol Blood Marrow Transplant. 2018;24(12):2558-2567. doi:10.1016/j.bbmt.2018.06.026

30. Piemontese S, Ciceri F, Labopin M, et al.; on behalf of the Acute Leukemia Working Party of the European Society for Blood and Marrow Transplantation (EBMT). A comparison between allogeneic stem cell transplantation from unmanipulated haploidentical and unrelated donors in acute leukemia. J Hematol Oncol. 2017;10(1):24. doi:10.1186/s13045-017-0394-2.

31. Kasamon YL, Luznik L, Leffell MS, et al. Nonmyeloablative HLA-haploidentical bone marrow transplantation with high-dose posttransplantation cyclophosphamide: effect of HLA disparity on outcome. Biol Blood Marrow Transplant. 2010;16(4):482-489. doi:10.1016/j.bbmt.2009.11.011

32. Solomon SR, Aubrey MT, Zhang X, et al. Selecting the best donor for haploidentical transplant: impact of HLA, killer cell immunoglobulin-like receptor genotyping, and other clinical variables. Biol Blood Marrow Transplant. 2018;24(4):789-798. doi:10.1016/j.bbmt.2018.01.013

33. Fleischhauer K, Shaw BE. HLA-DP in unrelated hematopoietic cell transplantation revisited: challenges and opportunities. Blood. 2017;130(9):1089-1096. doi:10.1182/blood-2017-03-742346

34. Fleischhauer K, Shaw BE, Gooley T, et al. Effect of T-cell-epitope matching at HLA-DPB1 in recipients of unrelated-donor haemopoietic-cell transplantation: a retrospective study. Lancet Oncol. 2012;13(4):366-374. doi:10.1016/S1470-2045(12)70004-9

35. Petersdorf EW, Carrington M, O'hUigin C, et al. Role of HLA-B exon 1 in graft-versus-host disease after unrelated haemopoietic cell transplantation: a retrospective cohort study. Lancet Haematol. 2020;7(1):e50-e60. doi:10.1016/S23523026(19)30208-X

36. Kollman C, Spellman SR, Zhang M-J, et al. The effect of donor characteristics on survival after unrelated donor transplantation for hematologic malignancy. Blood. 2016;127(2):260-267. doi:10.1182/blood-2015-08-663823

37. Kollman C, Howe CWS, Anasetti C, et al. Donor characteristics as risk factors in recipients after transplantation of bone marrow from unrelated donors: the effect of donor age. Blood. 2001;98 (7):2043-2051. doi:10.1182/blood.V98.7.2043

38. Canaani J, Savani BN, Labopin M, et al. Donor age determines outcome in acute leukemia patients over 40 undergoing haploidentical hematopoietic cell transplantation. Am J Hematol. 2018;93(2):246-253. doi:10.1002/ajh.24963

39. Ciurea SO, Shah MV, Saliba RM, et al. Haploidentical transplantation for older patients with acute myeloid leukemia and myelodysplastic syndrome. Biol Blood Marrow Transplant. 2018;24 (6):1232-1236. doi:10.1016/j.bbmt.2017.09.005

40. Rezvani AR, Storer BE, Guthrie KA, et al. Impact of donor age on outcome after allogeneic hematopoietic cell transplantation. Biol Blood Marrow Transplant. 2015;21(1):105-112. doi:10.1016/j.bbmt.2014.09.021

41. Mariotti J, Raiola AM, Evangelista A, et al. Impact of donor age and kinship on clinical outcomes after T-cell-replete haploidentical transplantation with PT-Cy. Blood Adv. 2020;4 (16):3900-3912. doi:10.1182/bloodadvances.2020001620 
42. Stern M, Brand R, de Witte T, et al. Female-versus-male alloreactivity as a model for minor histocompatibility antigens in hematopoietic stem cell transplantation. Am J Transplant. 2008;8(10):2149-2157. doi:10.1111/j.1600-6143.2008.02374.x

43. Kongtim P, Di Stasi A, Rondon G, et al. Can a female donor for a male recipient decrease the relapse rate for patients with acute myeloid leukemia treated with allogeneic hematopoietic stem cell transplantation? Biol Blood Marrow Transplant. 2015;21 (4):713-719. doi:10.1016/j.bbmt.2014.12.018

44. Passweg JR, Baldomero H, Bader P, et al.; for the European Society for Blood and Marrow Transplantation (EBMT). Hematopoietic SCT in Europe 2013: recent trends in the use of alternative donors showing more haploidentical donors but fewer cord blood transplants. Bone Marrow Transplant. 2015;50 (4):476-482. doi:10.1038/bmt.2014.312.

45. Anasetti C, Logan BR, Lee SJ, et al. Peripheral-blood stem cells versus bone marrow from unrelated donors. $N$ Engl $\mathrm{J} \mathrm{Med}$. 2012;367(16):1487-1496. doi:10.1056/NEJMoa1203517

46. Byrne M, Savani BN, Mohty M, Nagler A. Peripheral blood stem cell versus bone marrow transplantation: a perspective from the Acute Leukemia Working Party of the European Society for Blood and Marrow Transplantation. Exp Hematol. 2016;44 (7):567-573. doi:10.1016/j.exphem.2016.04.005

47. Savani BN, Labopin M, Blaise D, et al. Peripheral blood stem cell graft compared to bone marrow after reduced intensity conditioning regimens for acute leukemia: a report from the ALWP of the EBMT. Haematologica. 2016;101(2):256-262. doi:10.3324/ haematol.2015.135699

48. Teipel R, Oelschlägel U, Wetzko K, et al. Differences in cellular composition of peripheral blood stem cell grafts from healthy stem cell donors mobilized with either Granulocyte Colony-Stimulating Factor (G-CSF) alone or G-CSF and plerixafor. Biol Blood Marrow Transplant. 2018;24 (11):2171-2177. doi:10.1016/j.bbmt.2018.06.023

49. Schroeder MA, Rettig MP, Lopez S, et al. Mobilization of allogeneic peripheral blood stem cell donors with intravenous plerixafor mobilizes a unique graft. Blood. 2017;129(19):2680-2692. doi:10.1182/blood-2016-09-739722

50. Fisher SA, Lamikanra A, Dorée C, et al. Increased regulatory $\mathrm{T}$ cell graft content is associated with improved outcome in haematopoietic stem cell transplantation: a systematic review. Br J Haematol. 2017;176(3):448-463. doi:10.1111/bjh.14433

51. Edinger M, Hoffmann P, Ermann J, et al. CD4+CD25+ regulatory $\mathrm{T}$ cells preserve graft-versus-tumor activity while inhibiting graft-versus-host disease after bone marrow transplantation. Nat Med. 2003;9(9):1144-1150. doi:10.1038/nm915

52. Saraceni F, Shem-Tov N, Olivieri A, Nagler A. Mobilized peripheral blood grafts include more than hematopoietic stem cells: the immunological perspective. Bone Marrow Transplant. 2015;50(7):886-891. doi:10.1038/bmt.2014.330

53. Duval M, Klein JP, He W, et al. Hematopoietic stem-cell transplantation for acute leukemia in relapse or primary induction failure. J Clin Oncol. 2010;28(23):3730-3738. doi:10.1200/ JCO.2010.28.8852

54. Walter RB, Gyurkocza B, Storer BE, et al. Comparison of minimal residual disease as outcome predictor for AML patients in first complete remission undergoing myeloablative or nonmyeloablative allogeneic hematopoietic cell transplantation. Leukemia. 2015;29(1):137-144. doi:10.1038/leu.2014.173

55. Araki D, Wood BL, Othus M, et al. Allogeneic hematopoietic cell transplantation for acute myeloid leukemia: time to move toward a minimal residual disease-based definition of complete remission? J Clin Oncol. 2016;34(4):329-336. doi:10.1200/ JCO.2015.63.3826
56. Shayegi N, Kramer M, Bornhäuser M, et al. The level of residual disease based on mutant NPM1 is an independent prognostic factor for relapse and survival in AML. Blood. 2013;122 (1):83-92. doi:10.1182/blood-2012-10-461749

57. Norkin M, Katragadda L, Zou F, et al. Minimal residual disease by either flow cytometry or cytogenetics prior to an allogeneic hematopoietic stem cell transplant is associated with poor outcome in acute myeloid leukemia. Blood Cancer J. 2017;7 (12):634. doi:10.1038/s41408-017-0007-x

58. Jongen-Lavrencic M, Grob T, Hanekamp D, et al. Molecular minimal residual disease in acute myeloid leukemia. $N$ Engl $J \quad$ Med. 2018;378(13):1189-1199. doi:10.1056/NEJMoa 1716863

59. Rodríguez-Arbolí E, Labopin M, Tischer J, et al. FLAMSAbased reduced-intensity conditioning versus myeloablative conditioning in younger patients with relapsed/refractory acute myeloid leukemia with active disease at the time of allogeneic stem cell transplantation: an analysis from the acute leukemia working party of the European Society For Blood And Marrow Transplantation. Biol Blood Marrow Transplant. 2020;26(11):2165-2173. doi:10.1016/j.bbmt.20 20.07.020

60. Ustun C, Courville EL, DeFor T, et al. Myeloablative, but not reduced-intensity, conditioning overcomes the negative effect of flow-cytometric evidence of leukemia in acute myeloid leukemia. Biol Blood Marrow Transplant. 2016;22(4):669-675. doi:10.1016/j.bbmt.2015.10.024

61. Lint V. The combined effect of total body irradiation (TBI) and cyclosporin A (CyA) on the risk of relapse in patients with acute myeloid leukaemia undergoing allogeneic bone marrow transplantation: effect of TBI and CyA on post-transplant relapse in AML. Br J Haematol. 2000;108(1):99-104. doi:10.1046/j.13652141.2000.01809.x

62. Schmid C, Schleuning M, Ledderose G, Tischer J, Kolb H-J. Sequential regimen of chemotherapy, reduced-intensity conditioning for allogeneic stem-cell transplantation, and prophylactic donor lymphocyte transfusion in high-risk acute myeloid leukemia and myelodysplastic syndrome. J Clin Oncol. 2005;23 (24):5675-5687. doi:10.1200/JCO.2005.07.061

63. Steckel NK, Groth C, Mikesch J-H, et al. High-dose melphalan-based sequential conditioning chemotherapy followed by allogeneic haematopoietic stem cell transplantation in adult patients with relapsed or refractory acute myeloid leukaemia. $\mathrm{Br}$ J Haematol. 2018;180(6):840-853. doi:10.1111/bjh.15137

64. Doppelhammer M, Fraccaroli A, Prevalsek D, et al. Comparable outcome after haploidentical and HLA-matched allogeneic stem cell transplantation for high-risk acute myeloid leukemia following sequential conditioning - a matched pair analysis. Ann Hematol. 2019;98(3):753-762. doi:10.1007/s00277-019-03593-2

65. Stölzel F. From remission to cure: bypass or detour? $\mathrm{Br}$ J Haematol. 2018;180(3):317-318. doi:10.1111/bjh.15031

66. Clift R, Buckner C, Appelbaum F, et al. Allogeneic marrow transplantation in patients with acute myeloid leukemia in first remission: a randomized trial of two irradiation regimens [see comments]. Blood. 1990;76(9):1867-1871. doi:10.1182/blood. V76.9.1867.1867

67. Aoudjhane M, Labopin M, Gorin N, et al. Comparative outcome of reduced intensity and myeloablative conditioning regimen in HLA identical sibling allogeneic haematopoietic stem cell transplantation for patients older than 50 years of age with acute myeloblastic leukaemia: a retrospective survey from the Acute Leukemia Working Party (ALWP) of the European group for Blood and Marrow Transplantation (EBMT). Leukemia. 2005;19 (12):2304-2312. 
68. Martino R, de Wreede L, Fiocco M, et al.; for the Acute Leukemia Working Party the subcommittee for Myelodysplastic Syndromes of the Chronic Malignancies Working Party of the European group for Blood Marrow Transplantation Group (EBMT). Comparison of conditioning regimens of various intensities for allogeneic hematopoietic SCT using HLA-identical sibling donors in AML and MDS with $<10 \%$ BM blasts: a report from EBMT. Bone Marrow Transplant. 2013;48(6):761-770. doi:10.1038/bmt.2012.236.

69. Passweg JR, Baldomero H, Gratwohl A, et al.; for the European Group for Blood and Marrow Transplantation (EBMT). The EBMT activity survey: 1990-2010. Bone Marrow Transplant. 2012;47(7):906-923. doi:10.1038/bmt.2012.66.

70. Luger SM, Ringdén O, Zhang M-J, et al. Similar outcomes using myeloablative vs reduced-intensity allogeneic transplant preparative regimens for AML or MDS. Bone Marrow Transplant. 2012;47(2):203-211. doi:10.1038/bmt.2011.69

71. Scott BL, Pasquini MC, Logan BR, et al. Myeloablative versus reduced-intensity hematopoietic cell transplantation for acute myeloid leukemia and myelodysplastic syndromes. J Clin Oncol. 2017;35(11):1154-1161. doi:10.1200/JCO.2016.70.7091

72. Valcárcel D, Martino R, Piñana JL, Sierra J. Allogeneic stem cell transplantation after reduced-intensity conditioning for acute myeloid leukaemia: impact of chronic graft-versus-host disease. Curr Opin Oncol. 2009;21:S35-S37.

73. Rosenow F, Berkemeier A, Krug U, et al. CD34+ lineage specific donor cell chimerism for the diagnosis and treatment of impending relapse of AML or myelodysplastic syndrome after allo-SCT. Bone Marrow Transplant. 2013;48(8):1070-1076. doi:10.1038/ bmt.2013.2

74. Zeiser R, Blazar BR. Acute graft-versus-host disease - biologic process, prevention, and therapy. $N$ Engl J Med. 2017;377 (22):2167-2179. doi:10.1056/NEJMra1609337

75. Ferrara JL, Levine JE, Reddy P, Holler E. Graft-versus-host disease. Lancet. 2009;373(9674):1550-1561. doi:10.1016/ S0140-6736(09)60237-3

76. Kolb H-J. Graft-versus-leukemia effects of transplantation and donor lymphocytes. Blood. 2008;112(12):4371-4383. doi:10.1182/blood-2008-03-077974

77. Luznik L, O’Donnell PV, Symons HJ, et al. HLA-haploidentical bone marrow transplantation for hematologic malignancies using nonmyeloablative conditioning and high-dose, posttransplantation cyclophosphamide. Biol Blood Marrow Transplant. 2008;14 (6):641-650. doi:10.1016/j.bbmt.2008.03.005

78. Luznik L, O’Donnell PV, Fuchs EJ. Post-transplantation cyclophosphamide for tolerance induction in HLA-haploidentical bone marrow transplantation. Haploidentical Bone Marrow Transplant. 2012;39(6):683-693. doi:10.1053/j.seminoncol.2012.09.005

79. Ciurea SO, Zhang M-J, Bacigalupo AA, et al. Haploidentical transplant with posttransplant cyclophosphamide vs matched unrelated donor transplant for acute myeloid leukemia. Blood. 2015;126(8):1033-1040. doi:10.1182/blood-2015-04-639831

80. Mielcarek M, Furlong T, O'Donnell PV, et al. Posttransplantation cyclophosphamide for prevention of graft-versus-host disease after HLA-matched mobilized blood cell transplantation. Blood. 2016;127(11):1502-1508. doi:10.1182/blood-2015-10-672071

81. Robinson TM, O’Donnell PV, Fuchs EJ, Luznik L. Haploidentical bone marrow and stem cell transplantation: experience with post-transplantation cyclophosphamide. Altern Donor Transplant. 2016;53(2):90-97. doi:10.1053/j.seminhematol.20 16.01 .005

82. Ganguly S, Ross DB, Panoskaltsis-Mortari A, et al. Donor CD4+ Foxp3+ regulatory $\mathrm{T}$ cells are necessary for posttransplantation cyclophosphamide-mediated protection against GVHD in mice. Blood. 2014;124(13):2131-2141. doi:10.1182/blood-2013-10525873
83. Wachsmuth LP, Patterson MT, Eckhaus MA, Venzon DJ, Gress RE, Kanakry CG. Posttransplantation cyclophosphamide prevents graft-versus-host disease by inducing alloreactive $\mathrm{T}$ cell dysfunction and suppression. J Clin Invest. 2019;129 (6):2357-2373. doi:10.1172/JCI124218

84. Blazar BR, MacDonald KPA, Hill GR. Immune regulatory cell infusion for graft-versus-host disease prevention and therapy. Blood. 2018;131(24):2651-2660. doi:10.1182/blood-2017-11785865

85. Bertaina A, Roncarolo MG. Graft engineering and adoptive immunotherapy: new approaches to promote immune tolerance after hematopoietic stem cell transplantation. Front Immunol. 2019;10:13.

86. Kanakry CG, Bolaños-Meade J, Kasamon YL, et al. Low immunosuppressive burden after HLA-matched related or unrelated BMT using posttransplantation cyclophosphamide. Blood. 2017;129(10):1389-1393. doi:10.1182/blood-2016-09-737825

87. McCurdy SR, Kanakry CG, Tsai H-L, et al. Grade II acute graft-versus-host disease and higher nucleated cell graft dose improve progression-free survival after HLA-haploidentical transplant with post-transplant cyclophosphamide. Biol Blood Marrow Transplant. 2018;24(2):343-352. doi:10.1016/j.bbmt.2017.10.023

88. Blazar BR, Murphy WJ, Abedi M. Advances in graft-versus-host disease biology and therapy. Nat Rev Immunol. 2012;12 (6):443-458. doi:10.1038/nri3212

89. Ash RC, Horowitz MM, Gale RP, et al. Bone marrow transplantation from related donors other than HLA-identical siblings: effect of T cell depletion. Bone Marrow Transplant. 1991;7 (6):443-452.

90. Locatelli F, Merli P, Pagliara D, et al. Outcome of children with acute leukemia given HLA-haploidentical HSCT after $\alpha \beta$ T-cell and B-cell depletion. Blood. 2017;130(5):677-685. doi:10.1182/ blood-2017-04-779769

91. Martelli MF, Di Ianni M, Ruggeri L, et al. HLA-haploidentical transplantation with regulatory and conventional T-cell adoptive immunotherapy prevents acute leukemia relapse. Blood. 2014;124 (4):638-644. doi:10.1182/blood-2014-03-564401

92. Di Stasi A, Tey S-K, Dotti G, et al. Inducible apoptosis as a safety switch for adoptive cell therapy. $N$ Engl J Med. 2011;365 (18):1673-1683. doi:10.1056/NEJMoa1106152

93. Zhang Y-L, Zhu Y, Xiao Q, Wang L, Liu L, Luo X-H. Cytomegalovirus infection is associated with AML relapse after allo-HSCT: a meta-analysis of observational studies. Ann Hematol. 2019;98(4):1009-1020. doi:10.1007/s00277-018-3585-1

94. Kwekkeboom J. Potential beneficial effects of cytomegalovirus infection after transplantation. Front Immunol. 2018;9:11.

95. Ljungman P, Brand R, Hoek J, et al. Donor cytomegalovirus status influences the outcome of allogeneic stem cell transplant: a study by the European Group for Blood and Marrow Transplantation. Clin Infect Dis. 2014;59(4):473-481. doi:10.1093/cid/ciu364

96. Horowitz A, Guethlein LA, Nemat-Gorgani N, et al. Regulation of adaptive NK cells and CD8 T cells by HLA-C correlates with allogeneic hematopoietic cell transplantation and with cytomegalovirus reactivation. J Immunol. 2015;195(9):4524. doi:10.4049/ jimmunol.1401990

97. Cesaro S, Crocchiolo R, Tridello G, et al. Comparable survival using a CMV-matched or a mismatched donor for $\mathrm{CMV}+$ patients undergoing T-replete haplo-HSCT with PT-Cy for acute leukemia: a study of behalf of the infectious diseases and acute leukemia working parties of the EBMT. Bone Marrow Transplant. 2018;53 (4):422-430. doi:10.1038/s41409-017-0016-1

98. Yew PY, Alachkar H, Yamaguchi R, et al. Quantitative characterization of T-cell repertoire in allogeneic hematopoietic stem cell transplant recipients. Bone Marrow Transplant. 2015;50 (9):1227-1234. doi:10.1038/bmt.2015.133 
99. Noviello M, Manfredi F, Ruggiero E, et al. Bone marrow central memory and memory stem T-cell exhaustion in AML patients relapsing after HSCT. Nat Commun. 2019;10(1):1065. doi:10.1038/s41467-019-08871-1

100. Schmid C, Labopin M, Schaap N, et al. Prophylactic donor lymphocyte infusion after allogeneic stem cell transplantation in acute leukaemia - a matched pair analysis by the Acute Leukaemia Working Party of EBMT. Br J Haematol. 2019;184 (5):782-787. doi:10.1111/bjh.15691

101. Bornhauser M, Oelschlaegel U, Platzbecker U, et al. Monitoring of donor chimerism in sorted CD34+ peripheral blood cells allows the sensitive detection of imminent relapse after allogeneic stem cell transplantation. Haematologica. 2009;94 (11):1613-1617. doi:10.3324/haematol.2009.007765

102. Greco R, Oliveira G, Stanghellini MTL, et al. Improving the safety of cell therapy with the TK-suicide gene. Front Pharmacol. 2015;6. doi:10.3389/fphar.2015.00095

103. Anderson BE, McNiff J, Yan J, et al. Memory CD4+ T cells do not induce graft-versus-host disease. J Clin Invest. 2003;112 (1):101-108. doi:10.1172/JCI17601

104. Muffly L, Sheehan K, Armstrong R, et al. Infusion of donor-derived CD8+ memory $\mathrm{T}$ cells for relapse following allogeneic hematopoietic cell transplantation. Blood Adv. 2018;2 (6):681-690. doi:10.1182/bloodadvances.2017012104

105. Ghiso A, Raiola AM, Gualandi F, et al. DLI after haploidentical BMT with post-transplant CY. Bone Marrow Transplant. 2015;50 (1):56-61. doi:10.1038/bmt.2014.217

106. Schroeder T, Rachlis E, Bug G, et al. Treatment of acute myeloid leukemia or myelodysplastic syndrome relapse after allogeneic stem cell transplantation with azacitidine and donor lymphocyte infusions - a retrospective multicenter analysis from the German Cooperative Transplant Study Group. Biol Blood Marrow Transplant. 2015;21(4):653-660. doi:10.1016/j.bbmt.2014.12.016

107. Ruggeri L, Capanni M, Urbani E, et al. Effectiveness of donor natural killer cell alloreactivity in mismatched hematopoietic transplants. Science. 2002;295(5562):2097. doi:10.1126/ science. 1068440

108. Cooley S, Trachtenberg E, Bergemann TL, et al. Donors with group B KIR haplotypes improve relapse-free survival after unrelated hematopoietic cell transplantation for acute myelogenous leukemia. Blood. 2009;113(3):726-732. doi:10.1182/blood-200807-171926

109. Michaelis SU, Mezger M, Bornhäuser M, et al. KIR haplotype $\mathrm{B}$ donors but not KIR-ligand mismatch result in a reduced incidence of relapse after haploidentical transplantation using reduced intensity conditioning and CD3/CD19-depleted grafts. Ann Hematol. 2014;93(9):1579-1586. doi:10.1007/s00277-014-20842

110. Mancusi A, Ruggeri L, Urbani E, et al. Haploidentical hematopoietic transplantation from KIR ligand-mismatched donors with activating KIRs reduces nonrelapse mortality. Blood. 2015;125 (20):3173-3182. doi:10.1182/blood-2014-09-599993

111. Leung W, Iyengar R, Turner V, et al. Determinants of antileukemia effects of allogeneic NK cells. J Immunol. 2004;172 (1):644-650. doi:10.4049/jimmunol.172.1.644

112. Ruggeri L, Mancusi A, Capanni M, et al. Donor natural killer cell allorecognition of missing self in haploidentical hematopoietic transplantation for acute myeloid leukemia: challenging its predictive value. Blood. 2007;110(1):433-440. doi:10.1182/blood2006-07-038687

113. Ruggeri L, Vago L, Eikema D-J, et al. Natural killer cell alloreactivity in HLA-haploidentical hematopoietic transplantation: a study on behalf of the CTIWP of the EBMT. Bone Marrow Transplant. 2021;56(8):1900-1907. doi:10.1038/s41409-02101259-0
114. Strong RK, McFarland BJ. NKG2D and related immunoreceptors. Adv Protein Chem. 2004;68:281-312. doi:10.1016/S0065-3233(04)68008-9

115. Paczulla AM, Rothfelder K, Raffel S, et al. Absence of NKG2D ligands defines leukaemia stem cells and mediates their immune evasion. Nature. 2019;572(7768):254-259. doi:10.1038/s41586019-1410-1

116. Sanchez-Correa B, Gayoso I, Bergua JM, et al. Decreased expression of DNAM-1 on NK cells from acute myeloid leukemia patients. Immunol Cell Biol. 2012;90(1):109-115. doi:10.1038/ icb. 2011.15

117. Fauriat C, Just-Landi S, Mallet F, et al. Deficient expression of NCR in NK cells from acute myeloid leukemia: evolution during leukemia treatment and impact of leukemia cells in NCRdull phenotype induction. Blood. 2007;109(1):323-330. doi:10.1182/ blood-2005-08-027979

118. Mathew NR, Baumgartner F, Braun L, et al. Sorafenib promotes graft-versus-leukemia activity in mice and humans through IL-15 production in FLT3-ITD-mutant leukemia cells. Nat Med. 2018;24(3):282-291. doi:10.1038/nm.4484

119. Litjens NHR, van der Wagen L, Kuball J, Kwekkeboom J. Potential beneficial effects of cytomegalovirus infection after transplantation. Front Immunol. 2018;9:389. doi:10.3389/ fimmu.2018.00389

120. Ciurea SO, Schafer JR, Bassett R, et al. Phase 1 clinical trial using mbIL21 ex vivo-expanded donor-derived NK cells after haploidentical transplantation. Blood. 2017;130(16):1857-1868. doi:10.1182/blood-2017-05-785659

121. Maggs L, Kinsella F, Chan YLT, et al. The number of CD56dim NK cells in the graft has a major impact on risk of disease relapse following allo-HSCT. Blood Adv. 2017;1(19):1589-1597. doi:10.1182/bloodadvances.2017008631

122. Savani BN, Mielke S, Adams S, et al. Rapid natural killer cell recovery determines outcome after T-cell-depleted HLA-identical stem cell transplantation in patients with myeloid leukemias but not with acute lymphoblastic leukemia. Leukemia. 2007;21 (10):2145-2152. doi:10.1038/sj.leu.2404892

123. Buggins AGS, Milojkovic D, Arno MJ, et al. Microenvironment produced by acute myeloid leukemia cells prevents $\mathrm{T}$ cell activation and proliferation by inhibition of NF- $\kappa \mathrm{B}, \mathrm{c}-\mathrm{Myc}$, and $\mathrm{pRb}$ pathways. J Immunol. 2001;167(10):6021-6030. doi:10.4049/ jimmunol.167.10.6021

124. Colpitts SL, Stonier SW, Stoklasek TA, et al. Transcriptional regulation of IL-15 expression during hematopoiesis. J Immunol. 2013;191 (6):3017-3024. doi:10.4049/jimmunol.1301389

125. Cieri N, Camisa B, Cocchiarella F, et al. IL-7 and IL-15 instruct the generation of human memory stem $\mathrm{T}$ cells from naive precursors. Blood. 2013;121(4):573-584. doi:10.1182/blood2012-05-431718

126. Thiant S, Yakoub-Agha I, Magro L, et al. Plasma levels of IL-7 and IL-15 in the first month after myeloablative BMT are predictive biomarkers of both acute GVHD and relapse. Bone Marrow Transplant. 2010;45(10):1546-1552. doi:10.1038/bmt.2010.13

127. Burchert A, Bug G, Fritz LV, et al. Sorafenib maintenance after allogeneic hematopoietic stem cell transplantation for acute myeloid leukemia with FLT3 -internal tandem duplication mutation (SORMAIN). J Clin Oncol. 2020;38(26):2993-3002. doi:10.1200/JCO.19.03345

128. Munn DH, Sharma MD, Baban B, et al. GCN2 kinase in T cells mediates proliferative arrest and anergy induction in response to indoleamine 2,3-dioxygenase. Immunity. 2005;22(5):633-642. doi:10.1016/j.immuni.2005.03.013

129. Mussai F, De Santo C, Abu-Dayyeh I, et al. Acute myeloid leukemia creates an arginase-dependent immunosuppressive microenvironment. Blood. 2013;122(5):749-758. doi:10.1182/ blood-2013-01-480129 
130. Häusler SFM, Montalbán Del Barrio I, Strohschein J, et al. Ectonucleotidases CD39 and CD73 on OvCA cells are potent adenosine-generating enzymes responsible for adenosine receptor 2A-dependent suppression of $\mathrm{T}$ cell function and $\mathrm{NK}$ cell cytotoxicity. Cancer Immunol Immunother. 2011;60 (10):1405-1418. doi:10.1007/s00262-011-1040-4

131. Beavis Paul A, Stagg J, Darcy PK, Smyth MJ. CD73: a potent suppressor of antitumor immune responses. Trends Immunol. 2012;33(5):231-237. doi:10.1016/j.it.2012.02.009

132. Dulphy N, Henry G, Hemon P, et al. Contribution of CD39 to the immunosuppressive microenvironment of acute myeloid leukaemia at diagnosis. $\mathrm{Br} J$ Haematol. 2014;165(5):722-725. doi:10.1111/bjh.12774

133. Uhl FM, Chen S, O'Sullivan D, et al. Metabolic reprogramming of donor $\mathrm{T}$ cells enhances graft-versus-leukemia effects in mice and humans. Sci Transl Med. 2020;12(567):eabb8969. doi:10.1126/scitranslmed.abb8969

134. Jan M, Leventhal MJ, Morgan EA, et al. Recurrent genetic HLA loss in AML relapsed after matched unrelated allogeneic hematopoietic cell transplantation. Blood Adv. 2019;3(14):2199-2204. doi:10.1182/bloodadvances.2019000445

135. Vago L, Perna SK, Zanussi M, et al. Loss of mismatched HLA in leukemia after stem-cell transplantation. $N$ Engl J Med. 2009;361 (5):478-488. doi:10.1056/NEJMoa0811036

136. Waterhouse M, Pfeifer D, Pantic M, Emmerich F, Bertz H, Finke J. Genome-wide profiling in AML patients relapsing after allogeneic hematopoietic cell transplantation. Biol Blood Marrow Transplant. 2011;17(10):1450-1459.e1. doi:10.1016/j. bbmt.2011.07.012

137. Stölzel F, Hackmann K, Kuithan F, et al. Clonal evolution including partial loss of human leukocyte antigen genes favoring extramedullary acute myeloid leukemia relapse after matched related allogeneic hematopoietic stem cell transplantation. Transplantation. 2012;93 (7):744-749. doi:10.1097/TP.0b013e3182481113

138. Masuda K, Hiraki A, Fujii N, et al. Loss or down-regulation of HLA class I expression at the allelic level in freshly isolated leukemic blasts. Cancer Sci. 2007;98(1):102-108. doi:10.1111/ j.1349-7006.2006.00356.x

139. Dubois V, Sloan-Béna F, Cesbron A, et al. Pretransplant HLA mistyping in diagnostic samples of acute myeloid leukemia patients due to acquired uniparental disomy. Leukemia. 2012;26 (9):2079-2085. doi:10.1038/leu.2012.68

140. Crucitti L, Crocchiolo R, Toffalori C, et al. Incidence, risk factors and clinical outcome of leukemia relapses with loss of the mismatched HLA after partially incompatible hematopoietic stem cell transplantation. Leukemia. 2015;29(5):1143-1152. doi:10.1038/leu.2014.314

141. Barrett J, Blazar BR. Genetic trickery - escape of leukemia from immune attack. $N$ Engl $J$ Med. 2009;361(5):524-525. doi:10.1056/NEJMe0903177

142. Vago L, Ciceri F. Choosing the alternative. Biol Blood Marrow Transplant. 2017;23(11):1813-1814. doi:10.1016/j. bbmt.2017.09.009

143. Rovatti PE, Gambacorta V, Lorentino F, Ciceri F, Vago L. Mechanisms of leukemia immune evasion and their role in relapse after haploidentical hematopoietic cell transplantation. Front Immunol. 2020;11:147. doi:10.3389/fimmu.2020.00147

144. Zhukovsky EA, Morse RJ, Maus MV. Bispecific antibodies and CARs: generalized immunotherapeutics harnessing $\mathrm{T}$ cell redirection. Antigen Process Spec Sect New Concepts Antib Ther. 2016;40:24-35. doi:10.1016/j.coi.2016.02.006

145. Toffalori C, Zito L, Gambacorta V, et al. Immune signature drives leukemia escape and relapse after hematopoietic cell transplantation. Nat Med. 2019;25(4):603-611. doi:10.1038/ s41591-019-0400-z
146. Christopher MJ, Petti AA, Rettig MP, et al. Immune escape of relapsed AML cells after allogeneic transplantation. $N$ Engl $J$ Med. 2018;379(24):2330-2341. doi:10.1056/NEJMoa1808777

147. Norde WJ, Maas F, Hobo W, et al. PD-1/PD-L1 interactions contribute to functional T-cell impairment in patients who relapse with cancer after allogeneic stem cell transplantation. Cancer Res. 2011;71(15):5111-5122. doi:10.1158/0008-5472.CAN-11-0108

148. Greil R, Hutterer E, Hartmann TN, Pleyer L. Reactivation of dormant anti-tumor immunity - a clinical perspective of therapeutic immune checkpoint modulation. Cell Commun Signal. 2017;15(1):5. doi:10.1186/s12964-016-0155-9

149. Albring JC, Inselmann S, Sauer T, et al. PD-1 checkpoint blockade in patients with relapsed AML after allogeneic stem cell transplantation. Bone Marrow Transplant. 2017;52(2):317-320. doi:10.1038/bmt.2016.274

150. Davids MS, Kim HT, Bachireddy P, et al. Ipilimumab for patients with relapse after allogeneic transplantation. $N$ Engl $J$ Med. 2016;375(2):143-153. doi:10.1056/NEJMoa1601202

151. Ijaz A, Khan AY, Malik SU, et al. Significant risk of graft-versushost disease with exposure to checkpoint inhibitors before and after allogeneic transplantation. Biol Blood Marrow Transplant. 2019;25(1):94-99. doi:10.1016/j.bbmt.2018.08.028

152. Daver N, Boddu P, Garcia-Manero G, et al. Hypomethylating agents in combination with immune checkpoint inhibitors in acute myeloid leukemia and myelodysplastic syndromes. Leukemia. 2018;32(5):1094-1105. doi:10.1038/s41375-0180070-8

153. Daver N, Garcia-Manero G, Basu S, et al. Efficacy, safety, and biomarkers of response to azacitidine and nivolumab in relapsed/ refractory acute myeloid leukemia: a nonrandomized, open-label, phase II study. Cancer Discov. 2019;9(3):370-383. doi:10.1158/ 2159-8290.CD-18-0774

154. Ghosh A, Barba P, Perales M. Checkpoint inhibitors in AML: are we there yet? Br J Haematol. 2020;188(1):159-167. doi:10.1111/ bjh. 16358

155. Ehx G, Larouche J-D, Durette C, et al. Atypical acute myeloid leukemia-specific transcripts generate shared and immunogenic MHC class-I-associated epitopes. Immunity. 2021;54(4):737-752. e10. doi:10.1016/j.immuni.2021.03.001

156. Zeiser R, Vago L. Mechanisms of immune escape after allogeneic hematopoietic cell transplantation. Blood. 2019;133 (12):1290-1297. doi:10.1182/blood-2018-10-846824

157. Ambinder AJ, Levis M. Potential targeting of FLT3 acute myeloid leukemia. Haematologica. 2020;106(3):671-681. doi:10.3324/ haematol.2019.240754

158. Daver N, Schlenk RF, Russell NH, Levis MJ. Targeting FLT3 mutations in AML: review of current knowledge and evidence. Leukemia. 2019;33(2):299-312. doi:10.1038/s41375-018-0357-9

159. Kottaridis PD, Gale RE, Frew ME, et al. The presence of a FLT3 internal tandem duplication in patients with acute myeloid leukemia (AML) adds important prognostic information to cytogenetic risk group and response to the first cycle of chemotherapy: analysis of 854 patients from the United Kingdom Medical Research Council AML 10 and 12 trials. Blood. 2001;98 (6):1752-1759. doi:10.1182/blood.V98.6.1752

160. Stone RM, Mandrekar SJ, Sanford BL, et al. Midostaurin plus chemotherapy for acute myeloid leukemia with a FLT3 mutation. $N$ Engl $J$ Med. 2017;377(5):454-464. doi:10.1056/ NEJMoa1614359

161. Cortes JE, Khaled S, Martinelli G, et al. Quizartinib versus salvage chemotherapy in relapsed or refractory FLT3-ITD acute myeloid leukaemia (QuANTUM-R): a multicentre, randomised, controlled, open-label, phase 3 trial. Lancet Oncol. 2019;20 (7):984-997. doi:10.1016/S1470-2045(19)30150-0 
162. Perl AE, Martinelli G, Cortes JE, et al. Gilteritinib or chemotherapy for relapsed or refractory FLT3 -mutated AML. $N$ Engl $J$ Med. 2019;381(18):1728-1740. doi:10.1056/NEJMoa1902688

163. Mill CP, Fiskus W, DiNardo CD, et al. RUNX1-targeted therapy for AML expressing somatic or germline mutation in RUNX1. Blood. 2019;134(1):59-73. doi:10.1182/blood.2018893982

164. Phillips DC, Jin S, Gregory GP, et al. A novel CDK9 inhibitor increases the efficacy of venetoclax (ABT-199) in multiple models of hematologic malignancies. Leukemia. 2020;34 (6):1646-1657. doi:10.1038/s41375-019-0652-0

165. Bogenberger J, Whatcott C, Hansen N, et al. Combined venetoclax and alvocidib in acute myeloid leukemia. Oncotarget. 2017;8 (63):107206-107222. doi:10.18632/oncotarget.22284

166. Oellerich T, Mohr S, Corso J, et al. FLT3-ITD and TLR9 use Bruton tyrosine kinase to activate distinct transcriptional programs mediating AML cell survival and proliferation. Blood. 2015;125(12):1936-1947. doi:10.1182/blood-2014-06-585216

167. Göllner S, Oellerich T, Agrawal-Singh S, et al. Loss of the histone methyltransferase EZH2 induces resistance to multiple drugs in acute myeloid leukemia. Nat Med. 2017;23(1):69-78. doi: $10.1038 / \mathrm{nm} .4247$

168. Atanackovic D, Luetkens T, Kloth B, et al. Cancer-testis antigen expression and its epigenetic modulation in acute myeloid leukemia. Am J Hematol. 2011;86(11):918-922. doi:10.1002/ ajh. 22141
169. Goodyear O, Agathanggelou A, Novitzky-Basso I, et al. Induction of a CD8+ T-cell response to the MAGE cancer testis antigen by combined treatment with azacitidine and sodium valproate in patients with acute myeloid leukemia and myelodysplasia. Blood. 2010;116(11):1908-1918. doi:10.1182/ blood-2009-11-249474

170. Goodyear OC, Dennis M, Jilani NY, et al. Azacitidine augments expansion of regulatory $\mathrm{T}$ cells after allogeneic stem cell transplantation in patients with acute myeloid leukemia (AML). Blood. 2012;119(14):3361-3369. doi:10.1182/blood-2011-09-377044

171. Choi J, Ritchey J, Prior JL, et al. In vivo administration of hypomethylating agents mitigate graft-versus-host disease without sacrificing graft-versus-leukemia. Blood. 2010;116 (1):129-139. doi:10.1182/blood-2009-12-257253

172. Ørskov AD, Treppendahl MB, Skovbo A, et al. Hypomethylation and up-regulation of $P D-1$ in T cells by azacytidine in MDS/AML patients: a rationale for combined targeting of PD-1 and DNA methylation. Oncotarget. 2015;6(11):9612-9626. doi:10.18632/ oncotarget. 3324

173. Laport GG, Sheehan K, Baker J, et al. Adoptive immunotherapy with cytokine-induced killer cells for patients with relapsed hematologic malignancies after allogeneic hematopoietic cell transplantation. Biol Blood Marrow Transplant. 2011;17 (11):1679-1687. doi:10.1016/j.bbmt.2011.05.012

\section{Publish your work in this journal}

Cancer Management and Research is an international, peer-reviewed open access journal focusing on cancer research and the optimal use of preventative and integrated treatment interventions to achieve improved outcomes, enhanced survival and quality of life for the cancer patient.
The manuscript management system is completely online and includes a very quick and fair peer-review system, which is all easy to use. Visit http://www.dovepress.com/testimonials.php to read real quotes from published authors. 